University of Nebraska - Lincoln

DigitalCommons@University of Nebraska - Lincoln

Center for Great Plains Studies: Staff and

Fellows Publications

Great Plains Studies, Center for

Winter 2019

\title{
African American Homesteader "Colonies" in the Settling of the Great Plains
}

Jacob K Friefeld

Mikal Eckstrom

Richard Edwards

Follow this and additional works at: https://digitalcommons.unl.edu/greatplainsfellows

Part of the Agricultural and Resource Economics Commons, and the United States History Commons

This Article is brought to you for free and open access by the Great Plains Studies, Center for at DigitalCommons@University of Nebraska - Lincoln. It has been accepted for inclusion in Center for Great Plains Studies: Staff and Fellows Publications by an authorized administrator of DigitalCommons@University of Nebraska - Lincoln. 


\title{
African American Homesteader "Colonies" in the Settling of the Great Plains
}

\author{
JACOB K. FRIEFELD, MIKAL BROTNOV ECKSTROM, AND RICHARD EDWARDS
}

\begin{abstract}
African Americans participated in homesteading in the Great Plains primarily by establishing "colonies" or geographically concentrated homesteading communities. We studied Nicodemus, Kansas; DeWitty, Nebraska; Dearfield, Colorado; Empire, Wyoming; Sully County, South Dakota; and Blackdom, New Mexico, which were the largest and most important Black homesteading communities in their states. Black homesteaders, like their white counterparts, were mostly very poor, struggled to grow crops in a harsh climate, and used the land they gained to build new futures. But because of their previous experiences in the South and racism in some nearby communities, Black homesteaders developed a distinct understanding of their efforts, particularly of schooling and the "success" of their communities.
\end{abstract}

$\mathrm{D}$ uring the late nineteenth and early twentieth centuries, African Americans migrated to the Great Plains to participate in homesteading. Their numbers were not large

Key Words: Blackdom, Dearfield, DeWitty, Empire, Homestead Act, Nicodemus, racism

Jacob K. Friefeld holds a $\mathrm{PhD}$ in history from the University of Nebraska-Lincoln. He is currently a postdoctoral researcher at the Center for Great Plains Studies at the University of Nebraska-Lincoln. He is coauthor, with Richard Edwards and Rebecca Wingo, of Homesteading the Plains: Toward a New History (2017).

Mikal Brotnov Eckstrom is a postdoctoral researcher at the Center for Great Plains Studies. His written work includes a coauthored chapter with Margaret Jacobs in Why You Can't Teach US History without American Indians (University of North Carolina Press, 2012) and the Wall Street Journal.

Richard Edwards is director of the Center for Great Plains Studies, professor of economics, and senior vice chancellor (emeritus). Recent books include Atlas of Nebraska with J. Clark Archer and others (2017) and Natives of a Dry Place: Stories of Dakota Before the Oil Boom (2015).

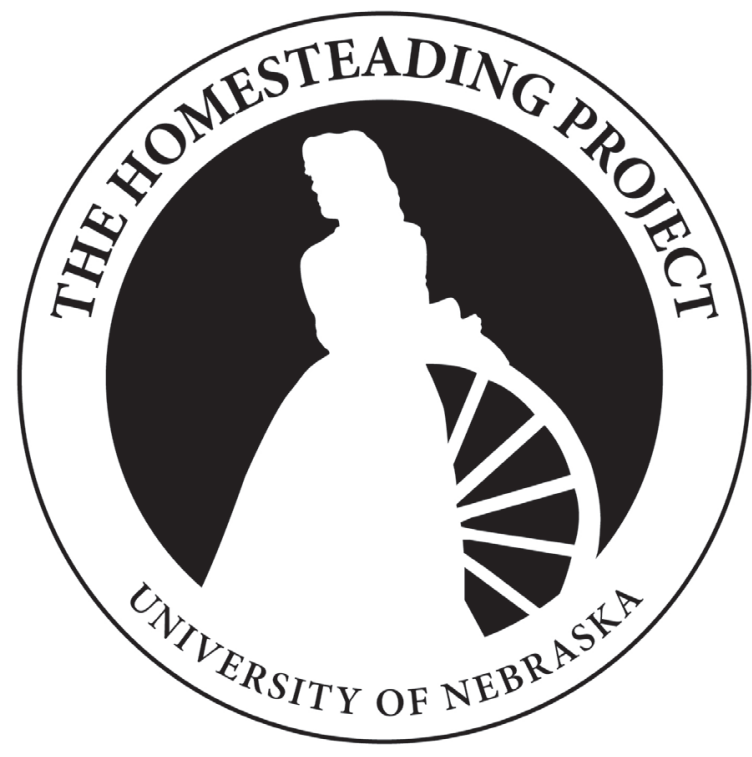


compared to whites, but they nevertheless established communities, started schools and churches, and created "places" of their own. As historian Timothy Nelson described it, "Black people were the town elders and controllers of daily life." The achievements and fates of these homesteaders are an important though oftenneglected part of Great Plains history.

We explore six African American homesteading communities in the Great Plains to see what Black homesteaders experienced and achieved and how their experiences were similar to or different from those of white homesteaders. We focus on Nicodemus, Kansas; Dearfield, Colorado; Empire, Wyoming; DeWitty, Nebraska; Sully County, South Dakota; and Blackdom, New Mexico (Fig. 1). We do not consider Black communities in the other Great Plains states. ${ }^{2}$ These six sites represent the largest, most long-lived, and most significant Black homesteader settlements in their respective states. Nicodemus is the most famous and the only one that persists to the present. It survives today as a very small community and a National Historic Site of the National Park Service. The others have disappeared, some identifiable by historic markers that have been erected, others only through archives and oral histories. Yet each has a vital story to contribute to the larger regional history, and together they help us appreciate the diversity of the homesteading movement.

These sites should be understood as rural neighborhoods or rural communities rather than towns, even though they are conventionally (mis)identified as towns. They were sites of concentrated Black homesteading, rural neighborhoods surrounding a tiny settlement or village (except for Nicodemus). Most of the population of these settlements resided on their homesteading claims in the country, not in "town," and the communities' achievements and eventual demise were largely determined by the success or failure of their constituent farm families. The town, or central core, typically provided only a meeting and trading space for the communities. Nicodemus was different, with its town as well as countryside being important, because the town grew large enough to generate its own dynamic. Thus we prefer the terms "community" or "colony," which we use interchangeably, except when we mean to refer specifically to the small village itself.

"Community" necessarily implies more indefinite boundaries, which matched the reality on the ground. It should include all those homesteaders who saw themselves, and in everyday life functioned, as part of the local society, whether or not their homestead lay within any particular borders. In Nicodemus, for example, there was the town, 160 acres platted and marked off into lots. Nicodemus Township, where most community residents lived, surrounded the town on three sides and spread over 22,880 acres. But some community members homesteaded in other Graham County townships adjacent to Nicodemus Township, and still others located in adjoining Rooks County, which Nicodemus Township bordered. All were effectively members of the Nicodemus "community." Some families both claimed a homestead and maintained a residence or business in town.

Black people were attracted to the Great Plains because they sought both to remove themselves from the violent and racist South and to become landowners in their own right. They were bitterly disappointed when southern whites during Reconstruction largely defeated federal land reform, leaving most Blacks landless, destitute, and at the mercy of white landowners. Those who sought to stake claims in 


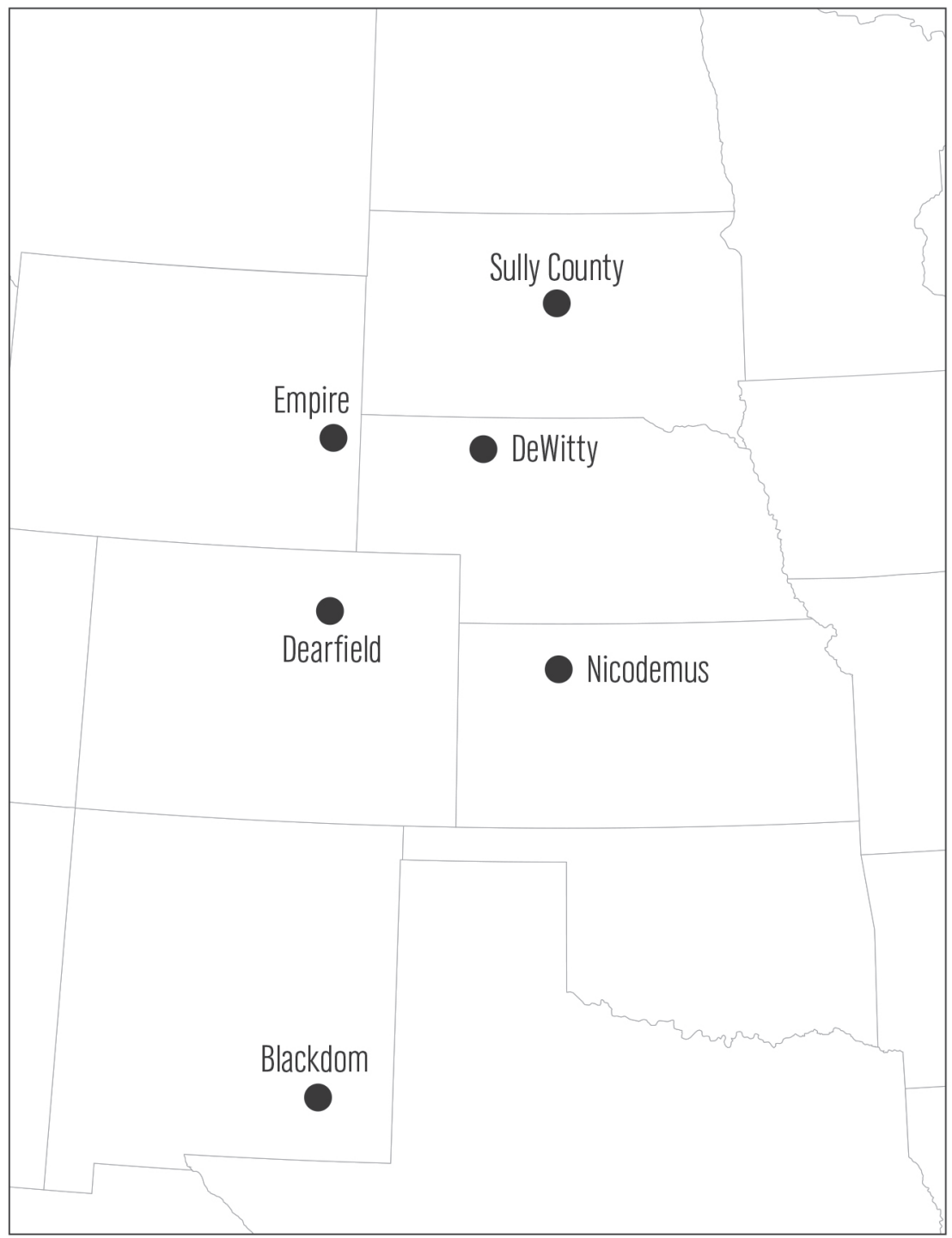

Data by authors, map by Katie Nieland

Fig. 1. Six Black homesteader communities in the Great Plains.

one of the five southern homestead states faced bitter and unremitting white hostility. And all southern Blacks suffered under the rising tide of white intimidation, beatings, and murder when federal troops were withdrawn in 1877.
The "free" South was a dangerous, oppressive, and vicious place for ex-slaves.

Robert H. Knox, a prominent Black leader in Montgomery, addressed an 1872 convention of African Americans, saying he had initially 
counseled them to remain in the South but now urged them to leave:

I yet would say let us rest here awhile longer; let us trust in God, the President, and Congress to give us what is most needed here, personal security to the laboring masses, the suppression of violence, disorder, and kukluxism, the protection which the Constitution and laws of the United States guarantee, and to which as citizens and men we are entitled. Failing in these, it is time, then, I repeat, to desert the State and seek homes elsewhere where there may be fruition of hopes inaugurated when by the hand of Providence the shackles were stricken from the limbs of four million men, where there may be enjoyed in peace and happiness by your own fireside the earnings of your daily toil. ${ }^{3}$

The Great Plains offered Black people an opportunity to start over, to claim land they could own themselves and on which they could build new futures. As a largely agricultural people in the South, both during slavery and afterward, they had developed skills and a deep knowledge of farming which they hoped to employ and so "enjoy in peace and happiness by [their] own fireside the earnings of [their] daily toil."

While Black colonies in the Great Plains experienced many of the same hardships and triumphs as white homesteader communities, they also encountered or developed distinctive features that shaped their experiences. The larger context of their efforts was important: like white homesteaders, they struggled to create successful farms in the harsh climate of the region; like whites they suffered from crop prices and freight costs that were set in far-off markets; and like whites they worked to build supportive communities to provide the cultur- al and civic benefits of longer-settled societies. But Black homesteaders differed from their white neighbors because of their horrendous experience in the South and enduring racism in some surrounding Great Plains communities. Other factors also shaped the Black homesteaders' experiences. In some cases Blacks were hindered in obtaining needed resources or saw their rights abused. Their situation led them to a very different understanding of what schooling meant. And they came to think of the "success" of their communities in a distinctive and revealing way.

\section{Six Black Homesteading Communities}

Not all Black communities were the same. Indeed, the histories and destinies of each was influenced by events, circumstances, and personalities unique to each. There has been substantial scholarly attention paid to the phenomenon of all-Black towns, especially in Oklahoma and Kansas, where organizers established many such towns. ${ }^{4}$ Less attention has been paid to Black homesteader settlement in other rural areas of the Great Plains. And to the extent that individual communities of Black homesteaders have been studied, they have largely been considered separately, without relation or comparison to the others. We begin with brief descriptions of the six communities.

\section{Nicodemus, Kansas}

In 1877 six Black entrepreneurs in Topeka joined with a local white developer to form the Nicodemus Town Company. They located their town in the Solomon River valley in north-central Kansas, a dry prairie environment. The first group of settlers, about thirty people, moved from Topeka, but the organizers quickly recruited much more widely, attract- 
ing approximately 300 migrants from Scott and Fayette Counties in Kentucky; they were followed by other "colonies" (groups) from Kentucky and Mississippi. Although as many as 500 to 700 people arrived between 1877 and 1879 , living conditions during these early years were so harsh, with most living in dugouts and food scarce, that many soon left.

Most who stayed filed homestead claims. As Kenneth Hamilton notes, "all but a few businessmen and others who could make a living in a frontier town resettled on homestead lands." By 1899 they had received eighty-eight homestead patents, making them owners of 13,350 acres. Although most attention has focused on the town of Nicodemus, its economic lifeblood was farming on homesteads in the surrounding Nicodemus Township. By the mid-188os, it was a moderately prosperous settlement, enjoying the highs when harvests were good but suffering lows when hit by drought, hail, and other prairie hazards. The population of the community eventually stabilized at around $300 .{ }^{5}$

The town also developed, and as early as 1879 , "the nucleus of the town had been formed, consisting of 35 dwellings, a general store, post office, hotel, real estate office, 2 livery stables, and 2 churches." Nicodemus attracted white merchants as well, and though far out-numbered by Blacks, whites actively participated in town life. Its residents quickly established schools, including Graham County's first school, as early as 1879 . So, too, its leaders were gaining political prominence in Graham County politics, in particular E. P. McCabe, who was appointed interim county clerk, a position that started him on his political career, and Abram Hall, who was Graham County census taker, a sensitive political position. McCabe went on to achieve statewide office, winning two elections as the Kansas state auditor. ${ }^{6}$
Two factors loomed very large in the prosperity of nearly every central Plains town during this period: whether it attracted a railroad line and whether it became the county seat. In the 188 os Nicodemus failed to achieve either one. Although several railroads intimated they would run tracks through Nicodemus, none did. And in the competition among area towns to become the county seat, Hill City won out. The loss of both the railroad and county seat to white towns nearby halted the town of Nicodemus's progress, and many merchants left for nearby Bogue, the railhead.

But while the town of Nicodemus declined after 1888, the farmers of Nicodemus Township persevered, suffering hard times when Great Plains agriculture struggled but also experiencing good times when it thrived. The Nicodemus project, initially organized as a for-profit speculative venture, always also contained the broader social goal of creating a safe community for African Americans. Nicodemus appears to have accomplished that goal for the farmers and families of Nicodemus Township: they had left behind a horrendous experience in the South and migrated at a time nationally of rising anti-Black violence and hostility, so Nicodemus must have seemed a community worth enduring hardship for.

\section{Dearfield, Colorado}

Dearfield was a Black community in Weld County, about seventy miles northeast of Denver, in Colorado's eastern shortgrass prairie, along the South Platte River. At its peak from 1917 to 1921, Dearfield may have housed as many as 300 residents. ${ }^{7}$ Oliver T. Jackson established the Negro Townsite and Land Company and founded the farming community in 1910. Nineteen settlers arrived in 1911, and their first winter was extremely difficult. "That winter," 
Jackson wrote, "only two of us had wooden houses, and the suffering was intense. We had scarcely any wood to burn. Buffalo chips and sagebrush was our chief fuel." ${ }^{8}$ Some lived in dugouts and tents, and three of their six horses died. They scavenged wood from along the South Platte River and in the coulees.

By 1915 they had constructed forty-four wooden cabins on their homestead claims, and by one estimate had put up over a hundred miles of fence. Additional settlers arrived, boosting the population to 111. In spite of the obstacles, by 1919 residents had received patents on thirty-seven homestead claims, covering 6,720 acres. $^{9}$ In 1918 Dearfield homesteaders harvested their first significant marketable crops, netting them over \$50,000, a huge payout allowing them to buy farm equipment, upgrade their stock, and make home improvements. The town also began to attract businesses; residents organized a company to manufacture concrete blocks and opened a lumber and coal yard and a boardinghouse with store attached. A hotel, restaurant, and other businesses followed. Many residents found employment with surrounding white ranchers and in the town of Greeley. ${ }^{10}$

So, too, Dearfield residents began to develop a cultural life for the community. Two churches provided regular services. ${ }^{11}$ The churches likely played a major role in other cultural initiatives, as they often do in many rural communities. Residents also opened a school, and the town hosted an annual festival and carnival, attracting prominent outsider speakers, including Colorado governor George Alfred Carlson.

Demand for Dearfield's farm products, pumped up by World War I, created increasing prosperity in the community, but the relatively wet 1910 gave way to the drier 1920 and then the extreme drought of the 1930s, shrinking yields at the same time that crop prices collapsed. Wheat prices, which had ranged between $\$ 2.00$ and \$2.50 per bushel between 1916 and 1920, fell to around $\$ 1.00$ per bushel in the 1920 and sagged below 50 cents per bushel in the early 1930s. World War I also reduced the flow of new Black migrants from the South, diverting them to northern cities with jobs in stockyards and factories. Dearfield's population plummeted after 1921. Just how rapidly the community cleared out is difficult to say, but the Black population by 1925 appears to have been but a tiny fraction of its 1921 level. ${ }^{12}$

\section{Empire, Wyoming}

The multibranched Speese and Taylor families farmed successfully for a quarter century near Westerville, Nebraska, but in 1908, "disgusted by racism, inadequate financial support for existing schools, and possibly legal problems with their land claims, [they] again heard the Sirens' song when the Ansley (Neb.) newspaper reported newly irrigated land available in eastern Wyoming," the Equality State. ${ }^{13}$ Their move may also have been triggered by concern that the family's original farms did not provide enough land for the multiplying families of the next generation. So they migrated again, to found Empire, in Goshen County, right along the state's eastern edge next to the Nebraska border. $^{14}$

Charles and Rosetta Speese and three of Charles's brothers and families moved to Empire. Charles Speese made a claim for 320 acres under the Enlarged Homestead Act, and Joseph Speese made a Desert Land claim for 160 acres. Soon two Taylor families, headed by Otis and Baseman, arrived; Baseman was married to Maggie Shores, member of 


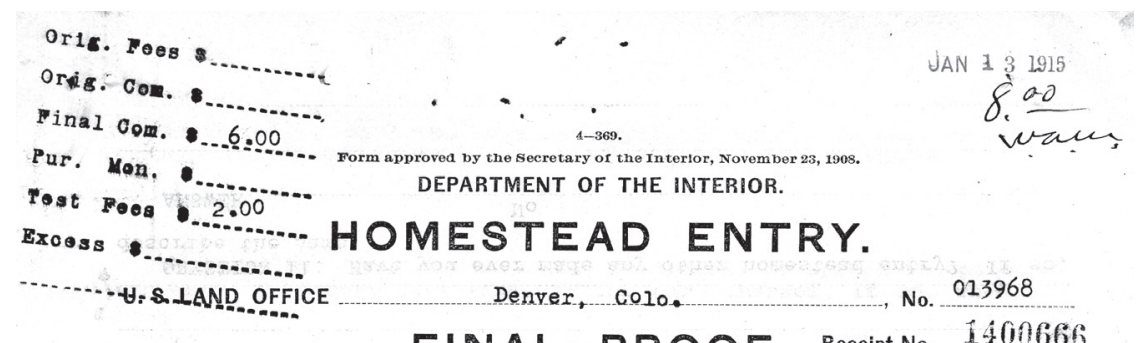

$160 \mathrm{As}$

FINAL PROOF. Receipt No. 1400666

1.25 per TESTIMONY OF CLAIMANT.

QUESTION 1. What is your full name, age, and post-office address?

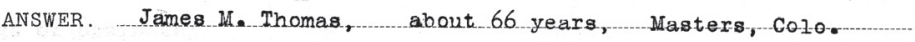

QUESTION 2. Are you a native-born citizen of the United States, and if so, in what State or Territory were you born? (If foreign born, see Note 1.)

ANSWER. Native, Alabame

QUESTION 3. Are you the same person who made Homestead Entry No.

013968 , at the Denver Land office on the

$8 / 30 / 10$ day of . 19 ........, for the

\begin{tabular}{|c|c|}
\hline $2 N+\frac{1}{4}$ & , Section 32 \\
\hline
\end{tabular}

ANSWER .

QUESTION 4. (a) Are you married or single? ANSWER. Married.

(b) If married, of whom does your family consist?

ANSWER. Wife \& 2 children.

(c) If a married woman, state whether your husband now has an unperfected homestead entry, and during what time he has resided on this land with you?

ANSWER.

QUESTION 5. (a) When did you first establish actual residence upon this land?

ANSWER. Dec. 17,1910

(b) When was your house built on this land?

ANSWER Nov. 1913; we lived in house house.

ANSWER. Hor. 1913i we lived in a house tent until we finighed

(0) Have either you or your family ever been absent from the homestead since establishing residence?

ANSWER. Have not been away since I filed nor my family

(d) If there has been such absence give the dates covered by each absence; and as to each absence state whether you, your family, or both, were thus absent and the reason for each such absence?

ANSWER .

Fig. 2. Image from the homestead file of James M. Thomas, Dearfield, Colorado. Records of the Bureau of Land Management Collections, National Archives. 
another multibranched and interwoven Black farm family from Nebraska. Nathan Taylor and his wife had already arrived in the area. In 1911 Russel Taylor, a minister and educator, arrived and filed a homestead claim. In all, ten homesteaders received patents by 1929 for 2,741 acres. $^{15}$

These families arrived with capital to invest in their new farms from their successful ventures in Nebraska. Their status was reflected in the houses they built. No dugouts are mentioned. Some put up substantial sod houses, but in fact most dwellings in Empire appear to have been frame farmhouses. The exact population of Empire is not known; there were thirty-six Blacks in Empire in 1910. In the following years, a number of large families, including Russel and Henrietta Taylor and their seven children, moved into Empire, raising the community's population to perhaps sixty or more. ${ }^{16}$

Taylor quickly became not only Empire's most distinguished citizen but perhaps the most prominent person in Goshen County. He was well educated, having graduated from Bellevue College, a Nebraska institution run by the Presbyterian Church. He may also have earned a graduate degree in divinity from Bellevue or an institution in Kansas. In Empire, he set to work organizing and leading the Empire schools. He also obtained a post office for the community, which opened in 1912 with himself as postmaster. That year he also recruited thirty residents to organize Grace Presbyterian Church, for which he served as pastor.

Empire residents were victims of several local racial incidents, including one traumatic murder. Their community broke into factions, and their farms produced meager results in the harsh, dry, unforgiving climate. They began leaving in 1916 for new opportunities, some moving just a few miles south to get better ac- cess to water from the new interstate canal, and others returning to Nebraska. By 1920, Empire had largely emptied out. ${ }^{17}$

\section{Sully County, South Dakota}

In 1882 African Americans began moving to Sully County, twenty miles north of Pierre in central South Dakota, when two brothers, Benjamin P. and Patrick H. Blair, arrived from Illinois to scout land for their family to settle. When Sully County opened for homesteading in 1883 , they filed claims in sections 13 and 14 of Fairbank Township; the family patriarch, Norvel Blair, joined them in 1884 and homesteaded or purchased land as well. In so doing, the Blairs became the first residents of what would later become the Sully County Colored Colony.

Migrants and speculators, both Black and white, were attracted to Sully County and especially to the town of Fairbank, because the Chicago and Northwestern Railroad appeared ready to build its line there. But the Chicago and Northwestern chose a different route, the speculators lost their investments, and many migrants departed. Norvel Blair and his family, however, survived the bust and stayed on, filing homestead claims and timber culture claims and purchasing land as well. They soon created a productive farm operation. A 1916 map of the township shows several Blairs (Norvel, Winnie, John Wesley, Mary Elizabeth, Benjamin P., Lucy, and Patrick H.) all owning land, usually quarter sections, in Fairbank Township, totaling 1,500 acres. Considering the Blairs and others, Black homesteaders obtained homesteading patents for twenty-nine claims totaling 5,170 acres. ${ }^{18}$

The Blair family was highly entrepreneurial. For a time Betty and Winnie Blair operated a restaurant and bakery in Pierre. Norvel raised 
Morgan horses, having brought his prized stock with him from Illinois. Benjamin and Patrick operated a livery in Fairbank. In 1896 Benjamin became the first African American in South Dakota to be a school board member, and he served as chairman of the Fairbank district school board for ten years. And in 1906 Benjamin Blair met with other Black South Dakotans in Yankton to form the Northwestern Homestead Movement, with a stated purpose of "bringing a better class of intelligent negroes from the southern states to South Dakota, to file on land in colonies and in the case of those having the means, to buy land outright." ${ }^{19}$

Black settlement in Sully County was boosted by this effort, driven by Blair entrepreneurial energies. Mary Elizabeth (Betty) Blair, a land agent, made a big sale in 1908 to John and Ellen McGruder and their children. John McGruder, a former slave, had prospered in Missouri, where among other enterprises he purchased the plantation on which he had been held a slave. In Sully County, the family ran 300 head of cattle, 3,00o sheep, and thirty racehorses and workhorses. Son William and his wife, Meta McGruder, farmed a half-section in Grandview township. ${ }^{20}$

The Black population of the Sully County Colored Colony remains uncertain, with estimates ranging from 80 to 200 , with total landholdings, including purchased land, of perhaps 8,00o acres. ${ }^{21}$ The Blairs, McGruders, and others recruited to Sully County remained active in and around the region from the 1890 s at least into the 1920s. Many were forced off the land during the Great Depression. Maxine McGruder, great-granddaughter of John McGruder, was said (in 1953) to be "the only Negro teaching at a white school in South Dakota." 22 Descendants of McGruders continue to live in the Pierre area.

\section{DeWitty, Nebraska}

"The Negro Homesteaders in the Sandhills were led there by my mother's father, Charles Meehan. He grew up in Detroit and Round Eau, Ontario, Canada, where my mother Rosetta, was born," wrote Ava Speese Day. "When they heard about the Kinkaid Act in Nebraska," she recalled, "grandfather and several others investigated and filed claims northwest of Brownlee, along the North Loup River." Earlier Meehan, an Irishman, his African American wife, Hester Meehan, and other family members had claimed homesteads in Custer County (Neb.); in 1907 they and others joined a small but growing Black settlement that had begun forming in 1904 and became known as DeWitty. ${ }^{23}$ It grew to be the most populous, long-lived, and successful settlement of Black homesteaders in Nebraska. ${ }^{24}$

The settlement grew in phases, with distinct groups of individuals from across the country. Eleven settlers filed homestead claims in 1907, three more in 1908, six in 1909, six in 1910, and twelve in 1911, for a total between 1904 and 1911 of forty-three entries, many of them along both sides of the North Loup River. By 1929 some fifty-six homestead claims for 29,402 acres had been proved up. Somewhat later Charles and Rosetta Speese, along with some other members of the Speese family, left Empire in 1920 and moved to DeWitty (in 1925 they would move again, to Sully County). From our examination of census and other records, it appears that the total number of Black people who at some point lived in DeWitty was between 155 and 171. DeWitty reached its population peak of 146 residents in 1915. In 1912, Miles H. DeWitty established and operated the post office and ran a small store alongside, apparently giving a name to the community. ${ }^{25}$

DeWitty parents placed a high priority on 


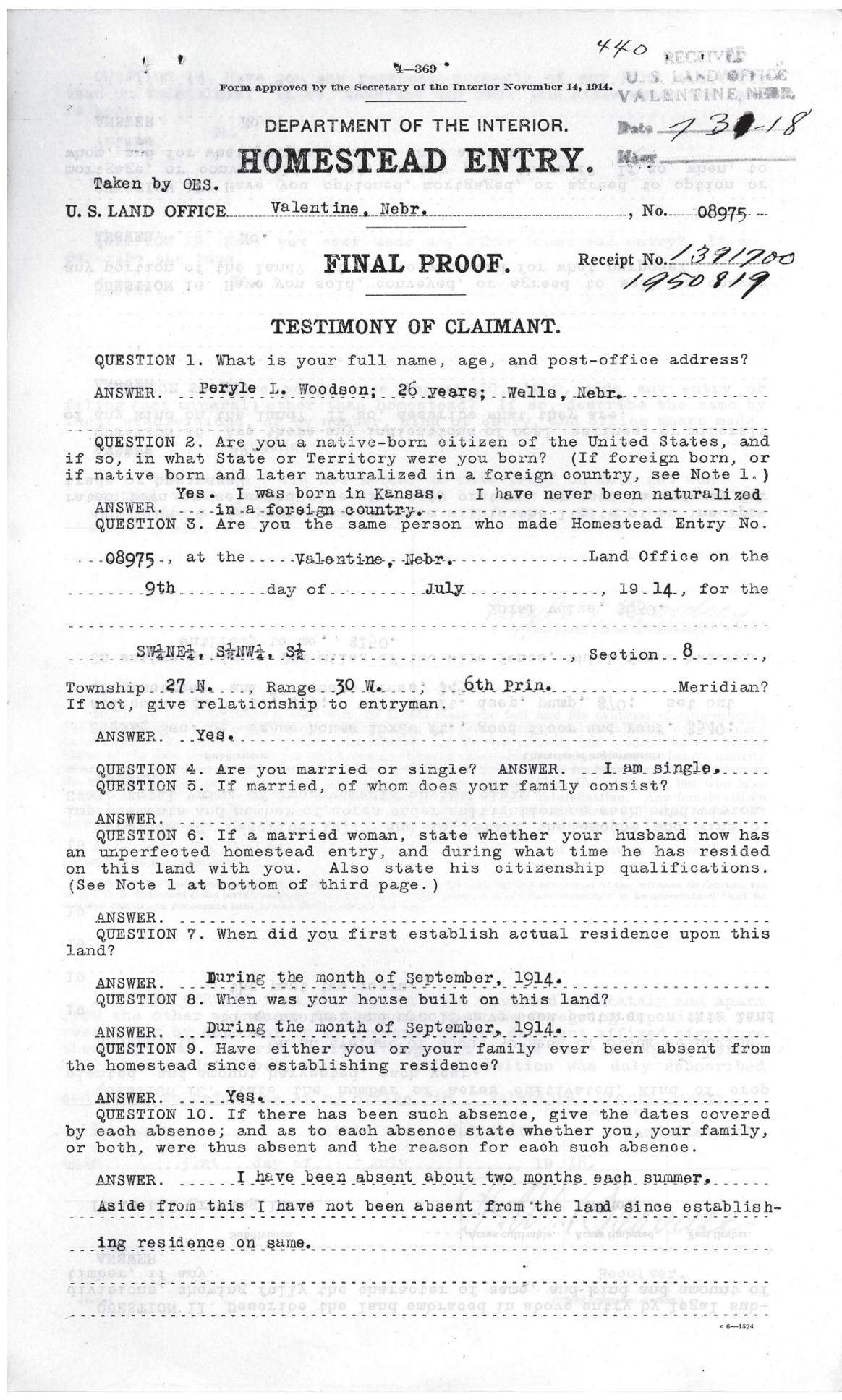

Fig. 3. Image from the homestead file of Peryle Woodsen, DeWitty, Nebraska. Records of the Bureau of Land Management Collection, National Archives. 
educating their children, establishing several school districts in areas where there were no white settlers and one that included both white and Black children. Most of the teachers were drawn from DeWitty itself. Much of DeWitty's social life revolved around the St. James African Methodist Episcopal (AME) Church, built in $1910 .{ }^{26}$ The residents also cultivated other important cultural pastimes-baseball, singing groups, reading circles, and so on-that drew the community together. The first Sunday of August was reserved for a big celebration and picnic for the entire DeWitty colony, featuring speeches, food and games, and sometimes a rodeo.

DeWitty, by then renamed Audacious, ultimately disappeared-by 1936 all of its settlers had sold out to ranchers and moved away. ${ }^{27}$ DeWitty homesteaders found the Sandhills to have difficult farming conditions-poor soil quality and, as late-comers, their claims often had inadequate access to water. In a familiar pattern, DeWitty had prospered during the 1900 and 1910s, wetter years during which crop prices were also relatively high (and very high during the war years). But starting in 1921, drier times returned and crop prices fell disastrously. When the stock market crashed and the long drought of the 1930 s arrived, DeWitty farmers like others could not survive. ${ }^{28}$ They borrowed where they could, mortgaging their land, but eventually sold out to adjoining ranchers. ${ }^{29}$

\section{Blackdom, New Mexico}

Blackdom, located fifteen miles south of Roswell, was first conceived by Frank Boyer and twelve other Roswell African Americans in 1903 when they formed the Blackdom Townsite Company with a putative capitalization of $\$ 10,000$. After some false starts, settlement began around 1909 in an area of desert prairies. The region received only about 12 to 13 inches of precipitation annually, though underground reservoirs and artesian wells offered hope of bolstering the poor rainfall with irrigation. Wetter years and increased white hostility to Blacks in Roswell (and nationally) may have stimulated the upsurge in interest in homesteading in Blackdom.

By 1929 residents received homestead patents on forty-nine claims, making them owners of 9,625 acres. Some residents filed for 160 acres under the Homestead Act, others for 320 acres under the Enlarged Homestead Act or the Desert Lands Act; the mean holding was 196 acres. The dozen or so leading families, many intertwined through kin and marriage relationships, included the Boyers, Herrons, Proffits, Collins, Eubanks, Wilsons, Smiths, and other families. At least twelve women homesteaded, several on their own and others perhaps to increase the family holdings. The community's exact population is unknown, but reasonable estimates suggest a figure of around 150 persons. ${ }^{30}$

Most residents occupied farms, but Blackdom developed a small village as well. It gained its own US post office in 1912. The town already had a schoolhouse, and during the succeeding decade its residents opened a store, built a new church, and added a pumping plant and what was termed an office building (probably containing land sales and legal offices).

As was almost always true in the Great Plains, Blackdom's prosperity was strongly dependent on adequate precipitation. From 1911 through 1923, rainfall in the area averaged 13.5 inches, marred only by the dry years of 1917, 1918, and 1922. Rainfall in the 1920s, however, was less plentiful and highly variable, and the disastrous decline in crop prices after World 
War I badly damaged Blackdom's farmers. The Blackdom post office closed in 1919. Blackdom began to empty out in the 1920s, though current records do not allow us to say by exactly how much. As Roosevelt Boyer Jr. remembered, "the demise of Blackdom was gradual and by the mid-1920s it was practically deserted." 31

However, there was one final installment in the Blackdom story, as Timothy Nelson discovered. ${ }^{32}$ National companies and local wildcatters discovered oil in the Roswell Basin and began buying leases and sinking exploratory wells. Blackdom residents, in order to make their land more attractive to major lease buyers and strengthen their bargaining power, pooled their lease rights and formed the Blackdom Oil Company. They agglomerated lease rights to perhaps 10,000 acres, and by March 1920 the company was reported to have entered a contract for 4,200 acres with the National Exploration Company in a deal perhaps worth up to $\$ 70,000$. The commercially viable producing fields turned out to be elsewhere, so the Blackdom lands did not ultimately pan out, and by the onset of the Great Depression, oil activity in the Roswell Basin largely came to an end. The Blackdom Oil Company's contracts and records of payouts have apparently not survived, so it is difficult to know with confidence, but probably Blackdom's hard-pressed homesteaders received some substantial funds from sale of their leases.

\section{Assessing the Experiences of Black Homesteader Colonies}

How are we to understand the enormous hard work expended, the risks faced, the hopes and dreams, the dangers and hardships and disappointments that Black homesteaders endured to create these communities? Since all except
Nicodemus have now disappeared, was the hard work wasted and the hardships endured in vain? Each community had its own unique circumstances, ambitions, personalities, and narrative, so seeking commonalities risks losing their individual and local character. Nonetheless, we propose that there were some commonalities. The larger context in which all homesteading occurred shaped Black as well as white fortunes. The special circumstances Blacks faced meant they also developed different features and ideas about their enterprise that made them distinctive.

\section{Shared Context of Homesteading}

Like most white homesteaders, African Americans came to the Great Plains because they wanted to own land and better themselves and their children's futures. Like whites, Black migrants were lured to the region by the promise of free land available to homesteaders. But as we note below, Black southerners' experience under slavery and vicious postwar labor contracts gave land ownership a different meaning for African Americans.

Once they reached the Great Plains, Black homesteader communities followed in broad outline the same pattern in their founding, growth, and decline as similar white settlements. During 1870-1895, white claimants created a flurry of filings in the central Plains (Kansas and Nebraska), built and extended farms, and founded nearby towns; during this period Nicodemus was founded, and the Speese, Shores, and other Black families established their farms around Overton and elsewhere in Nebraska. During the opening two decades of the twentieth century, white homesteaders moved into more remote areas, including the Nebraska Sandhills, eastern Colorado and Wyoming, the Dakotas, and 
New Mexico; this was when Black colonies at DeWitty, Dearfield, Empire, Sully County, and Blackdom were founded and prospered. And finally, after enjoying the agricultural boom of the opening two decades of the century, virtually all farmers suffered hard times in the 1920 and were mostly washed out by the 1930 s drought and depression-drought that caused their crops to wither, and depression that dried up opportunities for off-farm employment. The twin disasters hit Black farmers as well as white and caused both to abandon their land.

In more fine-grained ways, too, Black homesteaders shared circumstances similar to those of whites. One similarity was that several of the Black colonies were initially organized as for-profit enterprises, as were some white settlements. It was the fashion of the time for town developers and land investors to form corporations to plat and profit from town development. The prime movers who organized the Nicodemus Town Company, the (Dearfield) Negro Townsite and Land Company, and the Blackdom Townsite Company hoped to make profits by attracting investors, recruiting settlers, and selling town lots or memberships. These founders typically saw themselves as also "advancing the race" and did not see any conflict between that goal and profit-making. As entrepreneurs, they noticed that southern Blacks' desire to migrate to a safe community offering economic opportunities created a market demand that they, the entrepreneurs, sought to fill.

Empire, DeWitty, and Sully County, by contrast, developed into Black settlements more informally, without an organizing corporation or officially designated president or leader. In these cases, however, leading families played a crucial organizing role, and with their extensive kin and neighbor connections, they provided leadership to the settlement. They encouraged others to join their community, organized schools and churches, obtained a post office, planned town celebrations, and spread the word of the settlement's opportunities.

The two models tended to become more similar in practice as the settlements developed, for the simple reason that the towns usually turned out to be disappointing investmentsnone of the original investors appear to have received much profit. So, too, noncorporate residents insisted on taking part in community decision making, and over time their contributions were needed to fuel the settlement's continued development. Thus the leading families in each community came to be respected as the "town elders and controllers of daily life," in Nelson's phrase.

A second similarity was that residents of both Black and white communities sought to recreate the rich cultural and civic lives they had left behind (or create them, if their former communities denied them such comforts). Building a church, then a school, obtaining a post office, and opening a general store-even if, as they said about the Nicodemus store, it was "a generally-out-of-everything" storelinked isolated homesteading families to each other, to kin who remained behind, and to the wider world. They expended great effort on these community activities, even though most Black homesteaders, like most Norwegian, Bohemian, Jewish, and other homesteaders, were very poor. Their farms demanded virtually all their time, and their livelihoods were always at risk from the next hailstorm or drought or decline in crop prices. Nonetheless, they devoted precious and scarce resources-time, energy, emotions, and money-to enrich their cultural and civic lives. They hired teachers and pastors, organized baseball teams and traveled to 
games, organized reading circles and societies, solicited books from nearby or state libraries, and hosted huge community celebrations, especially on the Fourth of July and (variously named) Emancipation Day.

Making music and engaging in other hometown creative activities created community bonds. In DeWitty, for example, the Speese and Shores families were known to be musically talented, with the grown children being accomplished violinists and pianists. They formed the Jubilee Singers to put on sophisticated, high-culture performances of vocal and instrumental music. They were in demand and toured the surrounding towns. In Blackdom, singers from the church, according to the Artesia Pecos Valley News, toured to raise money to construct a church building: "A number of negroes from the Blackdom settlement up the valley came to Artesia Saturday afternoon and put on a very creditable performance in the Corringhall that night. The receipts went to the building fund of the Blackdom church. It is the intent of the troupe to give concerts at other places in the Valley." ${ }^{33}$

In addition to the practical purpose of fundraising, such touring must have also been an exhilarating break from the hardships of daily life. Scholarship has shown that African Americans created rich cultural lives for themselves even under the terrible and constraining conditions of slavery; now, in "places" of their own, they flourished. ${ }^{34}$

A third similarity between Black and white homesteader communities was the almost complete lack of serious crime in them. Black settlements were located in remote areas, no longer quite the "lawless frontier" but without developed criminal justice systems they could rely on. Empire, for example, was not far from the murderous four-year Johnson County War between the ranchers' hired gunmen and (white) homesteaders. Near Nicodemus, the notorious murder of John Landis capped off a decade-long reign of open killing and vigilante criminality in Norton County. DeWitty was not far from the enormous Spade Ranch, where Bartlett Richards and William Comstock conspired to steal 212,000 acres from the government and for which they were convicted and jailed.

Yet in the memoirs, letters, histories, and other writings about the six Black homesteader sites, we find almost no mention of crimes within those communities. It's not that there was no crime. In Nicodemus, for example, in 1879 there was a conflict about the distribution of aid contributed by outside charities, with allegations of pilfering. In 1880 there was an armed standoff in Roscoe when whites refused to let Nicodemus Blacks join the party. In 1886 Rev. John Anderson and Deacon J. Joseph got into a fistfight over interpreting a Bible verse. At the 1887 Emancipation Day celebration, there were several incidents-one involving a white man and white woman who got drunk and were charged with disorderly conduct, another a financial dispute between two Black men who exchanged shots and wounded a bystander, and a third, a fistfight between two visitors to town, one white and one Black. In Dearfield, someone outside the community created the only serious disturbance. In Blackdom, there are intimations that Frank Boyer and the other founders early on may have been junior partners in a significant land fraud organized by Chester and Benjamin Tallmadge, white land investors who were later indicted for land fraud and perjury. (We found no records or evidence of crimes in the other colonies.) Yet these cases are few and minor.

The lack of crime in the Black colonies was noticed by their white neighbors, at least when not in the grips of racist stereotypes. The Weld County News, for example, praised Dearfield's 
success, citing its two churches and school for "adding materially to the educational and moral standards of the community" and observing that "since the first filing within the colony [ten years earlier] there has been but one arrest for any offense of any magnitude and the offender in that instance was not legitimately a resident." ${ }^{35}$ In both Black and white homesteader settlements, close family ties and community (not police) enforcement tended to result in little crime.

A final similarity between the experiences of Black and white settlers was that homesteading was crucial to their success and to the flourishing of their communities. Recruiters seeking to induce settlers from the South, like those migrating from Kentucky and Tennessee to Nicodemus, emphasized the opportunity for landownership: "To farmers wanting homes there are 30,000 acres of fine, choice Government Land in the Great Solomon Valley subject to entry. Come and go to the Solomon Valley with us and plow deep, while the sluggards sleep."36

Owning their own land was the mark of economic freedom for Black migrants. Most had been an (unwilling) agricultural people under slavery and debt peonage, and they expressed their great hunger for owning land in the South before the white terrorists and racist politicians destroyed their hopes. What they knew was rural life, and their skills were agricultural. Most of them were also very poor, making purchase of land out of reach. They intended to earn their livelihoods as farmers, using the skills they already possessed. They were farmers, and they had come to claim land.

\section{Context and Consequences of Racism}

Despite the homesteading context that Black homesteaders shared with whites, they also faced a different reality, being Black in a racist society. The racial climate surrounding African
American colonies ranged from welcoming or neutral to hostile, although no community (so far as we know) experienced the kind of everyday violence and intimidation regularly visited upon Blacks in the South.

During these years, from roughly 1880 to 1925, the racial climate in the whole country turned increasingly hostile and violent toward Blacks. Southern states enacted Jim Crow laws, and the fact that Black families there lived on largely isolated sharecropping farms made them exceptionally vulnerable to $\mathrm{Ku}$ Klux Klan-type violence. During the twenty years from 1905 to 1924, white Americans lynched an average of fifty-six Black Americans every year. The Supreme Court in its notorious 1896 Plessy v. Ferguson decision declared that "separate but equal" segregation was constitutional. The Woodrow Wilson administration (1913 to 1921) proved to be a particular disaster for Blacks in government and other areas.

For African Americans setting out to homestead in unfamiliar physical and social surroundings, this ominous national climate must have created great anxiety about what they would find in their new neighborhoods. Norvel Blair, born into slavery, had built a successful farm and horse-raising enterprise in Illinois, but he abandoned it for Sully County after being cheated out of much of his Illinois property by a white lawyer. Roosevelt Boyer Sr., son of Blackdom founder Frank Boyer, when asked about how the whites treated the Blacks when they arrived in the Roswell area, responded, "At first whites didn't mind. They were all from the North [but] they soon all moved out and left the place to the Southerners. They didn't like nobody. They was hard on us as they could be." ${ }^{37}$ Moreover, Blacks who homesteaded in the Great Plains would live on their farms scattered across the landscape and be as isolated and as vulnerable to terrorist violence as Blacks in the 
South. And despite promises like those made to potential Nicodemus recruits-"Resolved, that this Colony shall have from one to two hundred militia, more or less, as the case may require, to keep peace and order"-no community had a hundred-man militia to protect it. ${ }^{38}$

Black homesteaders in the Great Plains were subjected to almost none of the violence they had suffered in the South. In all six communities, only one fatal incident, though a terrible one, is recorded: the beating, resulting in death, of Baseman Taylor by Goshen County sheriff's deputies while Taylor was in the deputies' custody. We consider this case in more detail elsewhere. ${ }^{39}$ The case surely reverberated at least among Empire, DeWitty, and Sully County, because residents of those communities were closely linked to Baseman Taylor through multiple kinship and marriage connections. (A white man, John Landis, who surveyed for Nicodemus claimants, was also killed, though it appears his connection to Nicodemus was not central to his murder. ${ }^{40}$ ) Aside from the Baseman Taylor case, however, we found no violent acts, personal assaults, or barn-burning or destruction of property directed at Blacks in these communities. ${ }^{41}$ Absence of physical abuse is undoubtedly a very minimal standard, but sadly, it is a relevant one. Compared especially to contemporaneous treatment of Blacks in the South, the lack of overt violence is notable.

That does not mean all the surrounding communities treated the newcomers humanely or as good neighbors. Black homesteaders were forced to interact with whites in nearby towns to do official business in the county courthouse or land office, to find off-farm work, to purchase supplies and materials, and to interact in the normal course of civic life. Even leaving aside the murder of Baseman Taylor, Wyoming proved to be one of the most hostile environ- ments. Empire's closest white town, Torrington, treated Black people degradingly, segregating its restaurants, hotels, and schools, and discriminating against Blacks in other ways. The local newspaper, the Torrington Telegram, was filled with offensive racial images, stereotypes, false reports, and caricatures. So too Blackdom residents found their surrounding society to be unsupportive, racist, and on occasion openly hostile, especially after its nearest white town, Roswell, filled with white immigrants from the South, as Roosevelt Boyer Sr. observed. The Roswell Daily Record, established in 1903, became a recurrent purveyor of racial slander, stereotyping, and race scares, adding to the town's toxic culture. ${ }^{42}$

Nicodemus experienced both helpful white behavior and racism. Whites (and Osage Indians) assisted Nicodemus settlers during the early, very difficult years when they needed food and other help. Charlotte Hinger describes several examples; in one case, "Uncle Johnny Furrow," a white, “'time and again' went as far east as Beloit, nearly ninety miles away, 'where he stocked up with a load of provisions, and going back [to Nicodemus] sought out the needy ones." By the mid-188os Black-white cooperation had grown and infused almost all activities. Although the vast majority of the residents were African American, town life was thoroughly biracial, as Claire O'Brien has carefully charted; she listed rosters by race for-all integrated-the emigration association, the land company, the school district officers, the literary society, the cornet band, the baseball club, the Grand Benevolent Society, and the Daughters of Zion. She noted the carefully ordered sequence of Fourth of July speakers, with Blacks and whites alternating. She and Kenneth Hamilton show how whites were among the town leaders who lobbied vig- 
orously to persuade the railroad companies to bring a track to Nicodemus. In these and many other ways, Blacks and (relatively few) whites appear to have lived, worked, socialized, politicked, and recreated harmoniously together. Nicodemus politicians, especially E. P. McCabe and Abram Hall, were appointed to county positions (and McCabe elected twice statewide), which could not have happened without major white support. ${ }^{43}$

Nicodemus's ledger also includes, however, jealousy and racial animosity from nearby Graham County towns. Some competition was to be expected among towns contending for the railroad line, for investors, and for designation as the county seat, but rude, racist treatment occasionally greeted Nicodemus residents when they journeyed for ordinary business to Hill City, Stockton, or Roscoe. Only one serious racial fight, in Roscoe, in December $188 \mathrm{o}$, is recorded, but several other incidents, which may initially have been motivated by other factors, took on a racial flavor. Suspicion also remains that both the railroads' decisions to bypass Nicodemus and Graham County's choice of Hill City rather than Nicodemus as county seat were racially influenced, but no direct evidence has been produced.

In contrast, Dearfield, DeWitty, and Sully County appear to have had friendly relations with nearby whites; we have found no recorded major racial incidents nor indeed even minor ones. In Dearfield, homesteaders often had to find off-farm work, which they did on neighboring ranches and in Greeley. DeWitty residents worked on neighboring ranches as farmhands and cooks. Irishman Charles Meehan and his Black wife, Hester Meehan, became one of DeWitty's most prominent couples, living for two decades in open violation of Nebraska's antimiscegenation law, with evidently no objections from white neighbors. In Sully County, the most prominent Black families, the Blairs and McGruders, built their multifaceted enterprises apparently without racial incident, or at least we have found no mention of any incidents if they occurred. ${ }^{44}$

We do not know all the small, subtle, or unseen ways in which racism may have harmed these communities. For example, the killing of Baseman Taylor enraged and embittered his brother, Russel Taylor, Empire's most important community leader. Russel Taylor repeatedly sought to bring to justice the sheriff's deputies, who were never charged with a crime, but every time he was thwarted, and it left him a changed man. His focus on that case likely distracted him from his community leadership, and Empire soon divided into factions, quarreling over the schools, churches, and other matters. Also suffering drought, Empire began to disintegrate, with key families moving away, perhaps in part a victim of racism.

\section{Education and Generational Transition}

Both Black and white homesteader communities placed a high priority on education, and there was much diversity within white communities-between Jewish and Mennonite, for example-on how they viewed schooling. Most white communities, like Black ones, established schools almost as soon as settlement occurred. Yet for former slaves and their children, education took on a special meaning.

Because slaves had been denied schooling and indeed were forbidden even to teach themselves how to read and write, Blacks understood becoming educated as essential to the definition of being free. Indeed, Rev. S. P. Roundtree, one of the Nicodemus founders, "wore a brand on one cheek as punishment for having received educational instruction 


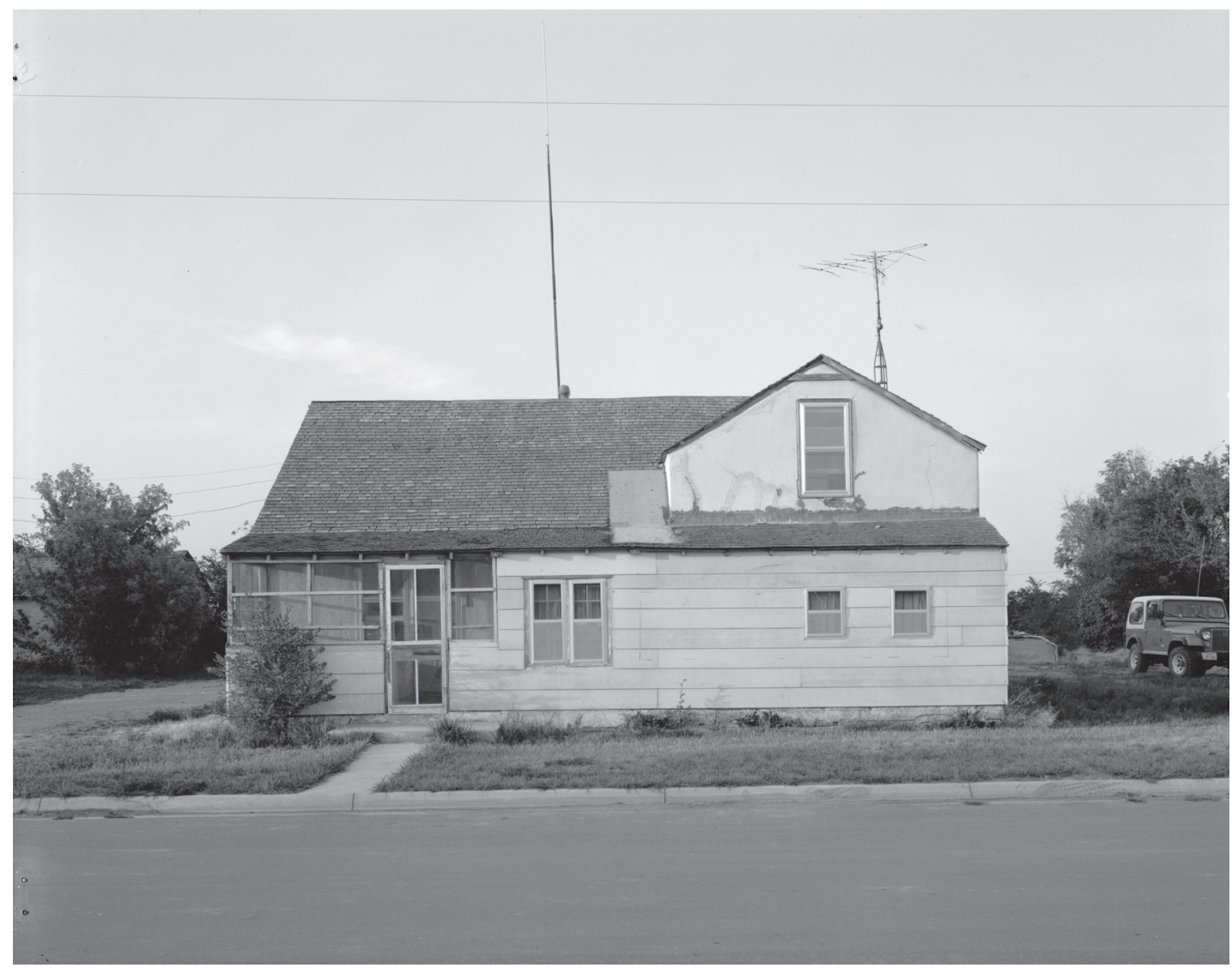

Fig. 4. Fletcher-Switzer House, Washington and Second Streets, Nicodemus, Graham County, Kansas. This building served as the St. Francis Hotel in the nineteenth century. Historic American Buildings Survey, Library of Congress, https://www.loc.gov/item/ks0124/.

from his master's son." This past imparted an urgency and deep significance to their efforts to create schools far beyond schooling's practical benefits. Of course, they also understood that literacy and math skills were important to their own everyday needs, to be able to read and analyze sales contracts, land documents, and newspapers, and they understood education as necessary for their children's future livelihoods. But they had as well this profound inspiration: educating their children marked them as free people. ${ }^{45}$

Little wonder, then, that colony residents organized schools nearly as soon as they arrived in their new settlements. In Nicodemus, the wife of $Z$. T. Fletcher opened a school in her dugout in $1877-78$, reportedly attended by forty-five students. In 1879 town leader Abram Hall presented a paper, "The Needs of the Race," in which he painted education as "the key which will unlock the door of caste [...] and consequently of wealth and bring us home, and make those homes the abode of intelligence." He insisted that education "was the key to the entire situation" that faced Black America. ${ }^{46}$ Hall's passion for education was 


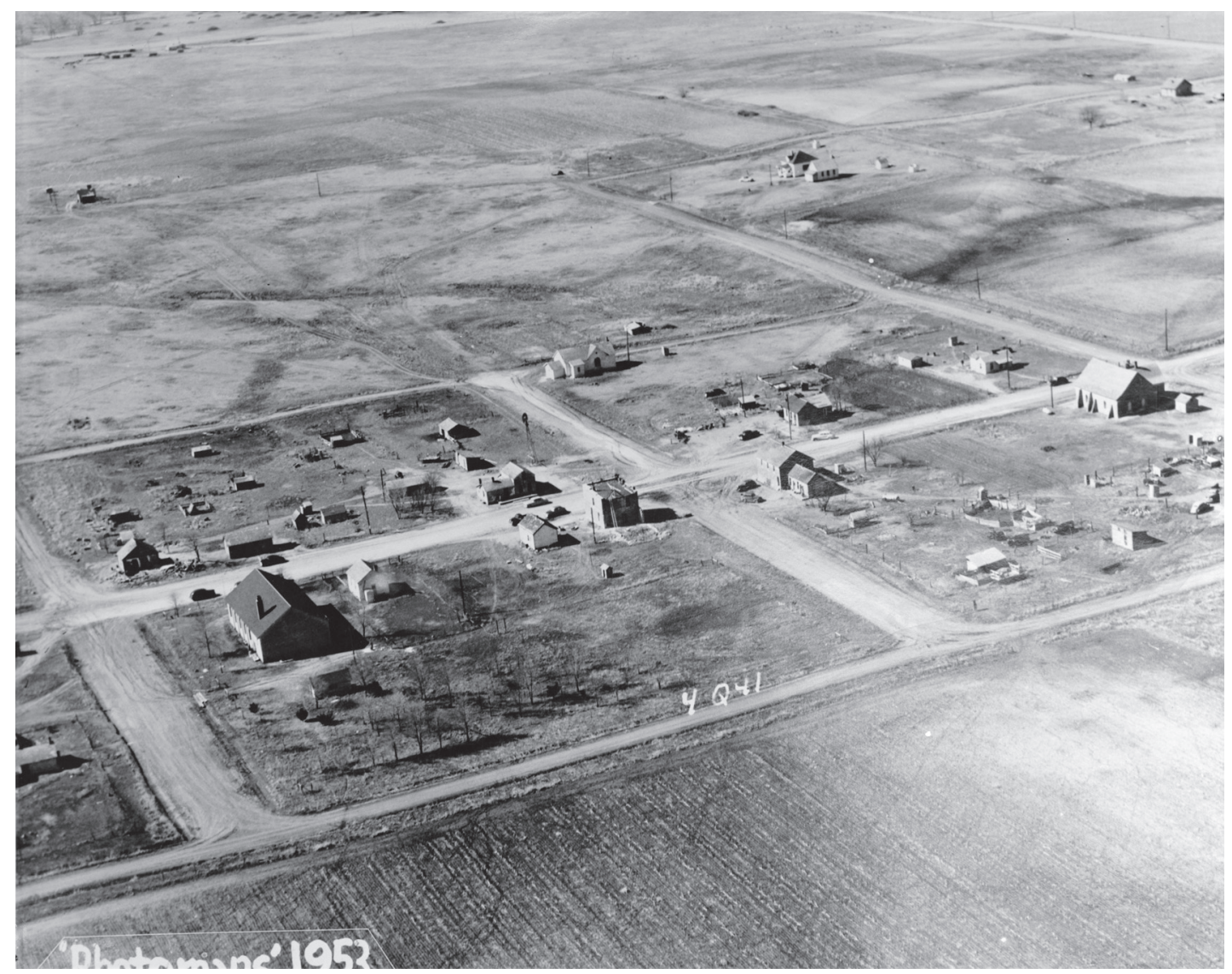

Fig. 5. Aerial view of Nicodemus from the northeast, 1953. Nicodemus Historic District, Graham County, Kansas, Historic American Buildings Survey, Library of Congress, https://www.loc.gov/item/ks0077/.

shared by most of his neighbors. John Samuels had learned to read in secret while enslaved in Tennessee; being able to read left a lasting impact on him, and he served on the committee to create Nicodemus's first town school in 1879 , the first public school in Graham County.

In Empire, too, as soon as the colony formed, its residents opened a school. In 1909-10 the community had hired a young Black woman, Sallie Thistle, to be the teacher in their one-room schoolhouse. The county school board authorized a new school building for Empire, one Russel Taylor called "one of the very best buildings in the county among rural schools." Wyoming state law prescribed segregated schools, at least "when there are fifteen or more Colored children" in a district, to keep Black children out of white schools, but segregation apparently was not much followed in practice. Initially, Empire cleverly applied this law in reverse to their own advantage, admitting only Black students. Taylor, when he assumed leadership of the school in 1911, reversed the policy, opening the school to white as well as Black children, but few whites attended, and soon the Empire School was again all Black. 
The school enrolled twenty-two students for 1912-13. After that, Taylor used the segregation law to maintain the autonomy of the Empire schools from the county board; in 1914, for example, he successfully protested the board's hiring of a white female teacher for Empire. ${ }^{47}$

The story was much the same in DeWitty, Dearfield, Sully County, and Blackdom-a school was quickly opened soon after settlement began, the community worked to construct a school building (which often was also used for church services), and young educated people from the community were hired as teachers. In Blackdom, the very articles of incorporation included an explicit commitment to develop schools for the residents of the town and surrounding countryside, presumably inserted because organizers thought that it would make Blackdom more attractive to recruits. When the board of the Greenfield school district, of which Blackdom was part, was unwilling either to integrate its school or build a separate Black school in Greenfield, Blackdom leaders convinced it instead to purchase the construction materials for a school in Blackdom and in 1909 the residents built their own school.

These were extremely poor communities whose residents necessarily worried about whether they would even survive. For them to put scarce resources of time and money into building schools and paying teachers showed both the high priority they placed on education and their vision that what they were building was a functioning community, a "place" that would feature all the necessary attributes of community life.

Perhaps growing out of the deep significance they attached to schooling, Black homesteader communities also appear to have developed a quite different understanding of why they were homesteading and what would constitute "success" in that endeavor. For most white homesteaders and communities, success was defined as building farms and communities that would persist over succeeding generations. The "loss" of children and grandchildren to cities and urban life and the "depopulation" of rural communities were marks of failure. The proudest boast of white farmers is some variation of "this farm has been in my family for five generations!" Blacks held a different view.

For many Black homesteaders, their farms were seen as a transitional phase, carrying them from the horrors of slavery and Reconstruction to some better future in which their descendants' lives were better but not necessarily tied to a family farm. Their "success" was thus not in whether future generations continued farming, but rather whether the homesteading generation equipped future generations with the life skills and education they would need to succeed in a wider world.

Two very practical problems reinforced this view. One was that to pursue higher education, which usually meant high school as well as anything higher, students had to leave their home communities. No Black community was able to open a high school. Thus, unless children ended their schooling around eighth grade, exit from the community (or at least temporary exit) was required. The Speese children at DeWitty, for example, attended high school and lived during that period in neighboring Thedford. Any additional education would take them further from home.

The second problem was deeper still. In small communities, eligible marriage partners for the new generation were very limited. The Shores, Taylor, and Speese families in the homesteader generation had intermarried to a significant extent, creating close and helpful kin 


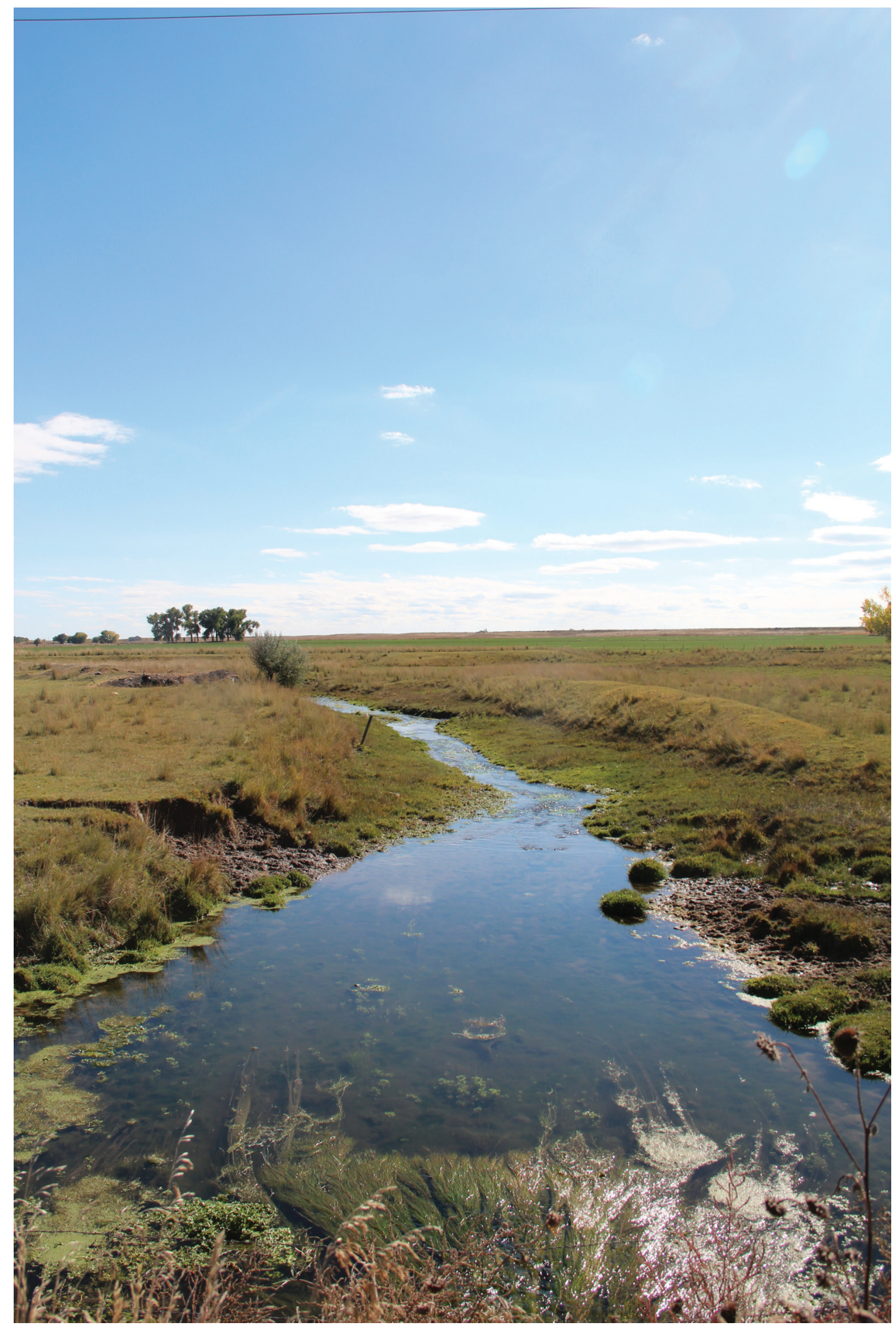

Fig. 6. Present-day view of Sheep Creek near the site of the Empire, Wyoming, settlement. (Photo by Jason Vlcan.) 
ties that provided mutual support. But that was more difficult to repeat in succeeding generations without violating norms of filial closeness. Moreover, although DeWitty's most prominent couple, Charles and Hester Meehan, a white man and Black woman, demonstrated that interracial marriages were possible, thus potentially greatly increasing the number of eligible partners, others apparently did not view their example as a realistic model. We have found no other interracial marriages among homesteaders in the six communities. So, to find marriage partners, young people in these communities increasingly had to search elsewhere.

Thus the "success" of Black communities as well as Black individuals became redefined. Residents focused less on whether the family farm or even the community persisted over many generations and more on how homesteading provided both a refuge for the homesteading generation and a staging area for the following generations, whose success was likely to occur elsewhere. This is the broader view of outcomes we need take into account when assessing what the Black colonies achieved.

For example, Nicodemus's town population would eventually dwindle to a mere handful, and to some it became (in Kenneth Hamilton's phrase) a "Black symbolic social center," made official when the National Park Service designated it a National Historic Site. ${ }^{48}$ Yet perhaps that judgment is too severe. The Nicodemus project, initially organized as a for-profit speculative venture, also always contained the broader social goal of creating a safe community for African Americans-a community where, in the words of Robert H. Knox, the Black leader in Alabama, Blacks could seek homes "where there may be enjoyed in peace and happiness by your own fireside the earnings of your daily toil." ${ }^{49}$ The settlement of Nicodemus appears to have accomplished this goal for the farmers and families of Nicodemus Township. At a time of rising national anti-Black violence and hostility, that was a significant achievement. Nicodemus became a home for people who risked everything to migrate there and start new lives, to the children who grew up there, to the entrepreneurs who operated successful businesses there, and to the farmers who created successful farms. That it later declined in numbers and many of its residents found new opportunities beyond Nicodemus perhaps only means that Nicodemus succeeded in laying the foundation for their success elsewhere.

DeWitty was built, prospered, and endured as long as it did because African American families made courageous decisions to take big risks to build better lives for themselves and their children. They faced long odds and must have known that their choice would require years or even decades of worry, sacrifice, and arduous toil. Their achievement was that they succeeded not only in providing material necessities for themselves but also in building a home community which embodied their hopes and dreams, in which for two decades or more they found opportunity and fulfillment.

A different way of seeing the Black colonies is that they created a temporary space, some lasting a dozen or two dozen years, Nicodemus much longer, between their horrific past of slavery and postbellum violence and their future of greater integration into American society. In that temporary space, they built farms, raised children and grandchildren, created schools, churches, and cultural lives for themselves, building their own "place" where "Black people were the town elders and controllers of daily life." Their true achievement may be seen in the lives of their children, grandchildren, and later descendants, who went on to lead productive, 


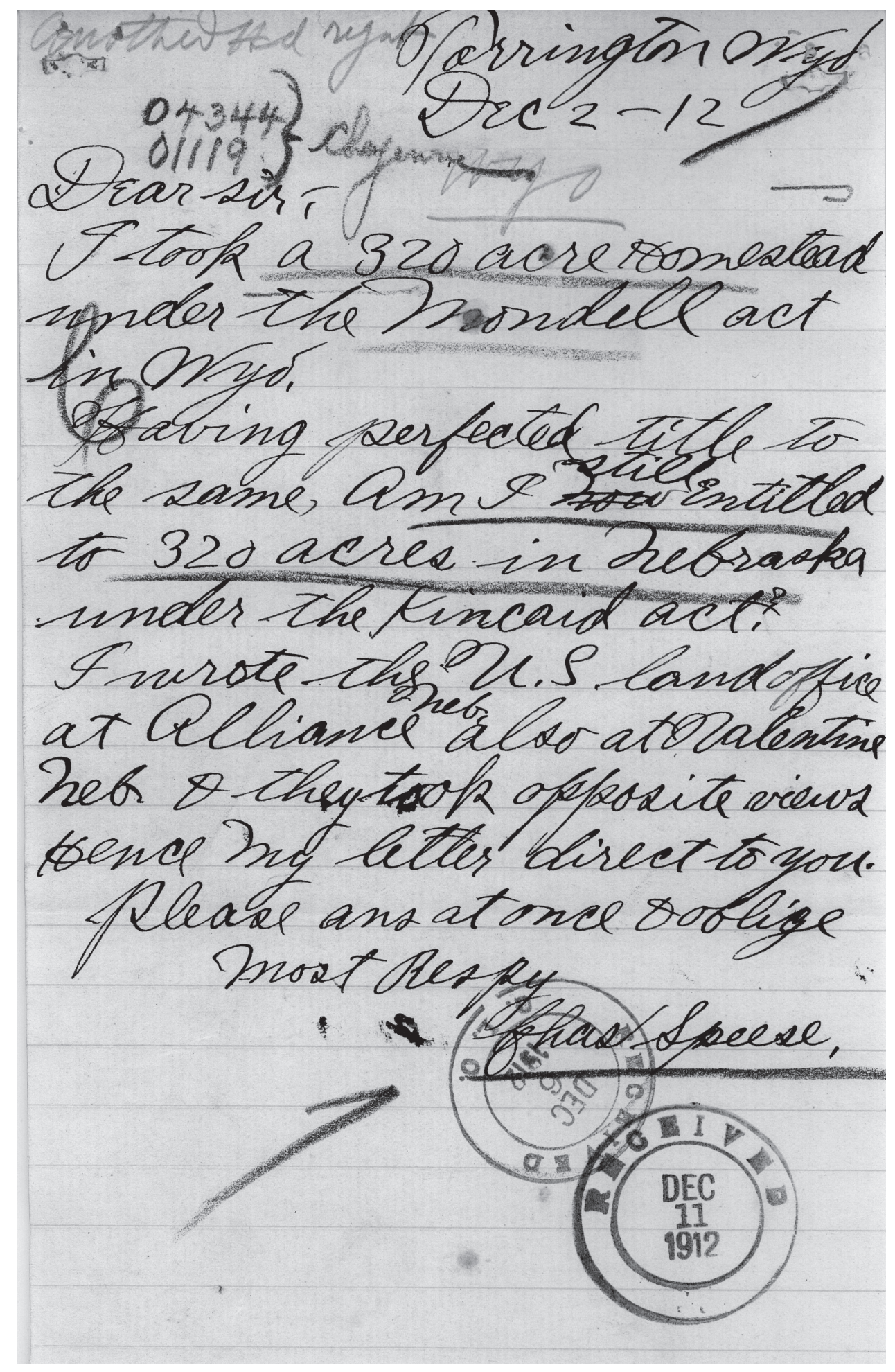

Fig. 7. An image from the homestead file of Charles Speese, Empire, Wyoming. Records of the Bureau of Land Management Collection, National Archives. 
successful, and fulfilling lives as pharmacists, educators, a mortician, nurses, postal clerks, authors, NFL players, and in one case, a cancer researcher at the Sloan Kettering Cancer Center in New York-just as their homesteader ancestors might have dreamed for them.

\section{Notes}

This research was supported in part by National Park Service grant \# $\mathrm{P}_{17} \mathrm{ACOO} 181$, which we gratefully acknowledge; all views expressed are those of the authors. We thank three anonymous reviewers for their helpful comments and our research assistants Jessica Carter, Sadie Counts, Crisanto Dubuc, and Katie Meegan for their excellent help.

1. Timothy Nelson, "The Significance of the AfroFrontier in American History: Blackdom, Barratry, and Bawdyhouses in the Borderlands, 1900-1930" (PhD diss., University of Texas at El Paso, 2015), ch. 20.

2. Although individual Blacks homesteaded in North Dakota and Montana, we do not discuss them because persistent Black homesteading communities were not created in these states. We do not analyze Black settlements in Oklahoma, because it has unusual and much more complicated racial configurations and cultures, a sometimes combustible mix of the South and the West, with African Americans, Indians, and whites, Indians who owned Black slaves, and other elements unique to the state. It deserves and has received substantial and excellent scholarly attention. We don't look at Texas, because it was not a public lands state governed by the Homestead Act, due to agreements made at the time of its annexation by the United States.

3. US Senate, 46th Congress, 2nd sess., Report 693, "Report and Testimony of the Select Committee of the United States Senate to Investigate the Causes of the Removal of the Negroes from the Southern States to the Northern States" (Washington: GPO, 1880), vi, $x$, xiii.

4. Kenneth Hamilton, Black Towns and Profit: Preemption and Development in the Trans-Appalachian West, 1877-1915 (Champaign: University of Illinois Press, 1991).

5. Kenneth Hamilton, "The Origins and Early Promotion of Nicodemus: A Pre-Exodus, All-Black
Town," Kansas History 5, no. 4 (Winter 1982), reprinted as "The Settlement of Nicodemus: Its Origins and Early Promotion," in Promised Land on the Solomon, National Park Service (Washington: Government Printing Office, 1986), 9; data developed from files of the General Land Office (GLO) and National Archives and Records Administration (NARA).

6. Clayton Fraser, "Nicodemus the Architectural Development and Decline of an American Town," in Promised Land on the Solomon, National Park Service (Washington: Government Printing Office, 1986), 4142; Charlotte Hinger, Nicodemus: Post-Reconstruction Politics and Racial Justice in Western Kansas (Norman: University of Oklahoma Press, 2016), 37, 20; Claire O’Brien, "With One Mighty Pull: Interracial Town Boosting in Nicodemus Kansas," Great Plains Quarterly 16 (Spring 1996): 119.

7. Estimates of the peak of Dearfield's population vary widely. Melvin Edward Norris Jr., "Dearfield, Colorado-The Evolution of a Rural Black Settlement: An Historical Geography of Black Colonization on the Great Plains" (PhD thesis, University of Colorado, Boulder, 1980), 158, puts the number at 700 residents in 1921 . However, Junne et al. suggest that figure is incorrect and "the actual number of Dearfield residents was more likely between 200 and 30o." George H. Junne Jr., Osita Ofoaku, Rhonda Corman, and Rob Reinswold, "Dearfield, Colorado: Black Farming Success in the Jim Crow Era," in Enduring Legacies: Ethnic Histories and Cultures of Colorado, ed. Arturo Aldama (Boulder: University of Colorado Press, 2011), 117n48.

8. Colorado Encyclopedia, "Dearfield," https:// coloradoencyclopedia.org/article/dearfield.

9. Norris, Dearfield, 139; homestead data developed from GLO and NARA files.

10. Norris, "Dearfield, Colorado," 164 . Norris gets this $\$ 50,000$ amount from a letter O. T. Jackson wrote in 1918. See Oliver T. Jackson to W. J. Harsha, December 5, 1918, Papers of Oliver T. Jackson, Paul W. Steward Collection, Denver Public Library, Western History Collection.

11. Quoted in Norris, "Dearfield, Colorado," 145, 164.

12. US Department of Agriculture, Bureau of Agricultural Economics, “The Wheat Situation," WSP 61, November, 1944, 1.

13. Todd Guenther, "Empire Builders, an African American Odyssey in Nebraska and Wyoming," Nebraska History 89 (2009): 184. 
14. Guenther, "Empire Builders", 177-79.

15. Guenther, "Empire Builders," 183-86; Yorick Nichols, US Department of the Interior Bureau of Land Management Records, Cheyenne Land Office, Township $23 \mathrm{~N}$, Range 6oW, Section 3, BLM Digital Archive, https://glorecords.blm.gov/details/patent /default.aspx?accession $=$ WY0140_..378\&docClass $=$ STA\&sid=r0ork31i.k1l; Russel Taylor, US Department of the Interior Bureau of Land Management Records, Cheyenne Land Office, Township 25N, Range 6oW, Section 3 and 4, BLM Digital Archive, https:// glorecords.blm.gov/details/patent/default.aspx $?$ accession $=608408 \&$ docClass $=$ SER $\&$ sid $=q 2 \mathrm{~h} 335 \mathrm{~m} 3$ .uki; Robert Galbreath, "Making a Home in Empire, Wyo., WyoHistory (A Project of the Wyoming State Historical Society), https://www.wyohistory.org /encyclopedia/making-home-empire-wyo. Homestead data developed from GLO and NARA files.

16. Robert Galbreath, "Empire, Wyoming," August 10, 2016, Alliance for Historic Wyoming, https://www .historicwyoming.org/profiles/empire-wyoming.

17. Guenther, "Empire Builders," 193.

18. "Fairbank Township, Little Bend Township" map, from Sully County 1916, South Dakota (Onida: Geo A. Ogle and Co., 1916); homestead data developed from GLO and NARA files.

19. Lila Morton Pengra, "Sully County Colored Colony," in BlackPast.org: Remembered and Reclaimed, http://www.Blackpast.org/aaw/blair -norvel-1825-1916; John Andrews, "Freedom in Sully County," South Dakota Magazine, February 4, 2014, http://www.southdakotamagazine.com/sully-county -colored-colony; Sully County Centennial History Book Committee, 100 Years of Proud People, 18831983: A History of Sully County (Onida, SD: Sully County Centennial History Book Committee, 1983), 283; Betti Vanepps-Taylor, Forgotten Lives: African Americans in South Dakota (Pierre: South Dakota State Historical Society Press, 2008), 97.

20. Vanepps-Taylor, Forgotten Lives, 97-98; Sully County Centennial, 100 Years, 283. George McGruder's final homesteading affidavit states that he owned 1,00o sheep every year since they filed. See RG49, F26993, George McGruder, Bureau of Land Management Files, NARA, Washington, DC.

21. John Andrews, "Freedom," 2; E. L. Thomas, ed., 75 Years of Sully County History, 1883-1958 (Onida, SD: Onida Watchman, 1959), 261; VaneppsTaylor, Forgotten, 98; Charles H. Rogge, "Early
History of Sully County" (master's thesis, University of South Dakota, 1936), 33.

22. Thompson, 75 Years, 261.

23. DeWitty is treated in detail in Mikal Brotnov Eckstrom and Richard Edwards, "Staking Their Claim: DeWitty and Black Homesteaders in Nebraska," Great Plains Quarterly 38, no. 3 (Summer 2018): 295-317.

24. Ava Speese Day, "Homesteading on the Plains: The Ava Speese Day Story," in African American Women Confront the West: 1600-200o, ed. Quintard Taylor and Shirley Ann Wilson Moore (Norman: University of Oklahoma Press, 2003), 119-21.

25. Many sources erroneously report that DeWitty (or Audacious, as it was renamed) was "disincorporated" or "dissolved" in 1936. However, Cherry County has no record of DeWitty ever being incorporated. Private communication from Sally Monroe, Deputy Clerk of Cherry County, Nebraska. John Farrar, "Black Homesteaders Settle the North Loup Valley” in NEBRASKAland, July 1998, 40; Charles Barron McIntosh, The Nebraska Sand Hills: The Human Landscape (Lincoln: University of Nebraska Press, 1996), 230; C. B. McIntosh, "Notes for DeWitty Paper \#2," 1907, 1974, 1978, 1980-1981, n.d., Papers of C. Barron McIntosh, RG5410.AM. S1 SS1 File 13, Nebraska State Historical Society, Lincoln, NE (hereafter referred to as "McIntosh Papers").

The population count does not include those who lived outside the bounds of the community but who nevertheless relied on the community for their social and economic needs. For example, not every person from Custer County moved to DeWitty. Some people remained, while others moved to Empire, Wyoming, or Alliance, Nebraska. Though the distance was long, those social and economic ties to the DeWitty community remained. Bertha W. Calloway and Alonzo N. Smith, Visions of Freedom on the Great Plains: An Illustrated History of African Americans in Nebraska (Virginia Beach: Donning Company Publishers, 1998), 30-32.

26. Ava Speese Day, "St. James RMC Church and Cemetery," in A Sandhill Century, Book 1: The Land (Valentine, NE: Cherry County Centennial Committee, 1985), 247; "Letter to Mrs. Walker from Ava Speese Day," March 28, 1964, Nebraska State Historical Society, Lincoln, NE; Frances Jacob Alberts, "Negro Homesteading in Nebraska," in Sod House Memories: A Treasury of Soddy Stories, ed. Frances 
Jacob Alberts (Holdrege, NE: The Sod House Society, 1972), 260; C. B. McIntosh, "Cherry County Historical Society Notes,” n.d., RG5410.AM. S1 SS1 File 6, McIntosh Papers.

27. C. B. McIntosh, "Ada Speese Day Correspondence," n.d., RG5410.AM. S1 SS1 File 2, McIntosh Papers.

28. "During the 1916-1919 period, U.S. corn prices averaged $\$ 1.35$ per bushel, a price not seen again until 1946. This price was $135.6 \%$ higher than the $\$ 0.57$ average price over the prior 10 years. With the end of World War I and the recovery of agriculture in Europe, prices fell precipitously.

"Over the next four years, U.S. corn prices averaged $\$ 0.61$ per bushel, a decline of $54.7 \%$ and over the full 1920-1940 interwar/Depression period, the price was not much different, averaging $\$ 0.65$ per bushel. There is some real justification for the complaint of farmers that they entered the Great Depression 10 years before the rest of the nation.

"The 21-year average includes two years when the price was $\$ 0.29$ per bushel, reflecting the failure of the Federal Farm Board's attempt to remove excess supplies from the market without including any provision for reducing production. Prices could fall that low because there were no programs to provide a floor on prices." Daryll Ray, "How Did Prices Fare Following Other Golden Eras in Agriculture?” March 25, 2015, http://www.agriculture.com/markets /analysis/corn/how-did-prices-fare-following-or -golden_9-ar48090.

29. "Letter to Mrs. Walker from Ava Speese Day," March 28, 1964, Nebraska State Historical Society, Lincoln, NE; McIntosh, Nebraska Sandhills, 237; Don Hanna Jr., "DeWitty Community, the Negro Settlement," in A Sandhill Century, 246-47.

30. Homestead data developed from GLO and NARA files; population estimate by Nelson, "Significance," 153.

31. Maisha Baton, "A History of Blackdom, NM, in the Context of the African American Post Civil War Colonization Movement," report to the Office of Cultural Affairs, Historic Preservation Division, State of New Mexico Project No. 35-95-10009.09 (Santa Fe, October 29, 1996), 13.

32. Timothy Nelson deserves full credit for discovering the genesis and role of the Blackdom Oil Company and its relation to Blackdom's final years; he treats it extensively in Nelson, "Significance," 154-59. Our treatment relies almost entirely on his research.

33. Quoted in University of New Mexico Earth Data Analysis Center, "Blackdom: The First All-Black Settlement in New Mexico-A Story Map," http://rgis .unm.edu/blackdom/.

34. Herbert G. Gutman, The Black Family in Slavery and Freedom, 1750-1925 (New York: Vintage Books, 1977); Eugene G. Genovese, Roll, Jordan, Roll: The World the Slaves Made (New York: Vintage Books, 1976); Brenda E. Stevenson, Life in Black and White: Family and Community in the Slave South (New York: Oxford, 1997); Anthony Kaye, Joining Places: Slave Neighborhoods in the Old South (Chapel Hill: University of North Carolina Press, 2007); and Philip D. Morgan, Slave Counterpoint: Black Culture in the Eighteenth-Century Chesapeake and Lowcountry (Chapel Hill: University of North Carolina Press, 1998).

35. "Weld County's Negro Colony," Weld County News, November 1921 (Harvest edition), 6o; Junne et al., "Dearfield," 110.

36. Nell Irvin Painter, Exodusters: Black Migration to Kansas after Reconstruction (Chicago: W.W. Norton, 1992), illustration following page 100.

37. Nelson, "Significance," 17; New Mexico History .org, "Roswell," http://newmexicohistory.org/places /roswell; Baton, "A History of Blackdom," 7.

38. The 100- to 200-man militia promise appeared in a widely disseminated poster, "All Colored People that Want to Go to Kansas on Sept 5, 1877 Can do so for $\$ 5.00$." There is no evidence such a militia was ever formed. The organizers' main concern may have been reflected in the concluding clause of the promise: "any member failing to pay in his dues, aforesaid, or failing to comply with the above rules in any particular, will not be recognized or protected by the Colony." Nicodemus Historical Society, 1877.

39. Eckstrom and Edwards, "Staking Their Claim." Todd Guenther labels this case a "lynching," although it seems to us more a case of police brutality.

40. Landis was brought in to Nicodemus Township to survey when Blacks could find no one else willing to do the job; soon after he was shot in the back. However, Landis had been in continual conflict-legal and extralegal, including several armed skirmishes-for ten years with Democratic 
vigilante "Regulators" in Norton County. When he moved to Kansas he "received the plaudits of his friends and the execrations of his enemies" and later his friends "were unable to decide which he enjoyed most" (38). His murder seemed to have been more related to this long conflict than to his Nicodemus work, though opposing views on race were part of the basic conflict. F. M. Lockard, The History of Early Settlement of Norton County, Kansas (Norton, KS: Norton Champion, 1894). Charlotte Hinger also discusses the murder, and appears to see a more direct connection to race, in her Nicodemus: PostReconstruction Politics and Racial Justice in Western Kansas (Norman: University of Oklahoma Press, 2016), 50-52.

41. Timothy Nelson recounts the long, sometimes cooperative, sometimes contentious, usually corrupt but occasionally priggish relationship between Roswell's best-known bordello operator, a Black woman named Mattie Moore (also known as Mittie Moore Wilson) and the Roswell police. It's not clear that this was racial harassment, though, as Nelson colorfully documents, there were certainly racial aspects to it. 42. Nelson, Blackdom.
43. Hinger, Nicodemus, 52; Hamilton, "Settlement of Nicodemus," 15-18; O’Brien, "With One Mighty Pull," 119-26.

44. Pengra, "Sully County Colored Colony"; Andrews, "Freedom in Sully County."

45. In Hamilton, "Settlement of Nicodemus," 2, quoting from the Federal Writers' Project, Kansas: A Guide to the Sunflower State (New York: Viking, 1939), 330-31.

46. Glen Schwendemann, "Nicodemus: Negro Haven on the Solomon," Kansas Historical Quarterly 34 (Spring 1978), 26; Hinger, Nicodemus, 84-85.

47. Guenther, "Empire Builders," 188-89. Guenther states that there was only one attempt to segregate, in Cheyenne, and it failed. Galbreath, "Empire, Wyoming," 2.

48. Hamilton, "Settlement of Nicodemus," 23-24. 49. US Senate, 46th Congress, 2nd sess., Report 693, "Report and Testimony of the Select Committee of the United States Senate to Investigate the Causes of the Removal of the Negroes from the Southern States to the Northern States," xiii. 